\title{
Study on the Present Situation of Ecological Environment and the Countermeasures of the Castle Peak Damage in Dandong
}

\author{
Bao Yuxue \\ Liaoning Geology Engineering Vocational College \\ Dandong, 118008, China
}

\begin{abstract}
The study is the general research project of science and technology of Liaoning Province in 2014, is the provincial science and technology research project. The purpose of the study is to protect the good ecological environment and manage and restore the damaged areas of the Dandong area. The study has summarized the reasons for the destruction of the Castle Peak in Dandong according to the production site visits and production practices and engineering reports and management information, etc. Mining development and construction land is the main reason for the destruction of the Castle Peak in the Dandong area. At the same time, the study puts forward some countermeasures for prevention and rehabilitation of Castle Peak damage from the government to the enterprise, from the policy to the action and so on according to China's actual situation. To strengthen the monitoring of the Castle Peak damage and the restoration of the damaged mountain is the key. It has directive significance on the work of the Castle Peak in Dandong area.
\end{abstract}

Keywords-The Countermeasures of the Castle Peak damage; The ecological environment; The damage cause; Dandong; The Castle Peak protection;

\section{INTRODUCTION}

Since twenty-first Century, China's economy has been rapid development, but the rapid economic development has brought environmental issues. Eighteen major Chinese Communist Party has clearly defined the construction of beautiful China as one of the development strategy. The construction of "beautiful China" is the construction of ecological civilization, is the well-being of the people, the nation's long-term future plans. We must adhere to the basic state policy of conserving resources and protecting the environment. We should vigorously promote green development, development of circular economy and low carbon development, and form a good environment for the people to create a good environment of production. The engineering of the repairing as the main content of the "green hills, clear water, blue sky" project to the ecological has been to carry out in 2011 Liaoning Province. Dandong has implemented the Castle Peak protection project, in order to enhance the protection of the Dandong area of the good ecological environment. [1] Dandong

The present situation of ecological environment in

\section{A. Natural survey of study area}

Dandong is located in the Liaodong Peninsula, is located in the West Bank of Yalu River and north of the
Yellow Sea, East and North Korea across the river, is China coast north end point. There is located in hilly area of Liaodong hilly accounted for $72.4 \%$, plain valley area accounted for $14.6 \%$, water accounted for $8.7 \%$, accounting for $4.3 \%$ of the other. From northeast to southwest tilt, the average elevation of $500 \mathrm{~m}$, Dandong City, Donggang City and south central and southern parts is the lowest, the coastal area is flat, as long as the narrow coastal plain.

\section{B. The current situation of forestry resources}

According to the related data Qingshan Bureau of Dandong, the control of modern forestry requirements, the existence of are as follows:

Forest structure performance shows: The proportion of remnant forest is more than high-quality forest; The total of woodland area is bigger but the unit volume of forest land is less ; The single conventional forestry management is more, but efficient stereo composite business is few less; the number of broadleaf trees is more than that of conifers; The number of young forest is more than it of mature forest; The proportion of ecological public welfare forest is more, but the area of effective economic forest and timber forest is less.[2 4]

The overall level of forest management and performance shows: The overall Forest quality is low, the utilization rate of comprehensive of forest is low, The level of science and technology of forestry management is low, The level of information management of forestry management is low, Forest comprehensive benefits is low, and economic output of forestry is low.

\section{Status quo of the development of mining economy in Dandong City}

Dandong is a big city of mineral resources in Liaoning Province, regional metallogenic conditions is superior, more varieties, wide distribution, and abundant reserves. Dandong mining industry has a long history, the output value of the mining industry and the follow-up industry accounted for $16 \%$ of the total industrial output value of the city. [5]

Dandong is in the key period of economic development now, the small mines of various building materials and stone are also contributing to the economic construction of Dandong area, and the mining industry plays an important role in the development of Dandong. 


\section{Biological abundance changes in Dandong area}

According to the Dandong municipal environmental monitoring center data, the biological abundance index change from 2006 to 2007 ,the following tab .1.

TABLE I DANDONG AREA BIOLOGIC AL ABUNDANCE INDEX CHANGE CONDITION

\begin{tabular}{|c|c|c|c|}
\hline $\begin{array}{c}\text { The name } \\
\text { of the area }\end{array}$ & $\mathbf{2 0 0 6}$ & $\mathbf{2 0 0 7}$ & $\begin{array}{c}\text { The rate } \\
\text { of change }\end{array}$ \\
\hline Dandong & 32.955 & 32.107 & $-2.57 \%$ \\
\hline Fengcheng & 70.387 & 69.251 & $-1.61 \%$ \\
\hline Kuandian & 78.669 & 74.724 & $-5.01 \%$ \\
\hline Donggang & 33.896 & 32.857 & $-3.07 \%$ \\
\hline
\end{tabular}

The table shows: In recent years, the biological abundance decreased in Dandong area, Prove that there is a downward trend in the quality of the ecological environment in Dandong area. We are should take corresponding measures to avoid further deterioration of the ecological environment in Dandong area.

\section{E. The survey of occupation forestry land in Dandong}

Because of the economic construction and mining development etc, so the increased demand for forest land, Mine occupation forestry land is nearly an half of the total number of all occupied land in 2012 in Dandong area, and Various Engineering construction land is nearly an half of the total too.

\section{DAMAGE CAUSE OF CASTLE PEAK IN DANDONG}

Through investigation and Research on the ecological environment of Dandong area, the main reasons of Castle Peak of damage are follows:

\section{A. Mining development cause $e^{[5]}$}

First, Because of the development and utilization of mineral resources, mining activity required for road, waste rock dump, mine construction land, resulting in land and woodland massive destruction, soil physical properties change, the effect of plant growth. According to 2012 statistics, mines and occupation of forest land is $1240.3 \mathrm{hm} 2$. Especially large open-pit mines, the destruction of vegetation on mountains, tailing huddle misplacing, lead to the original lush beautiful castle is full of scars, and some even became barren hills. Second, Influence of mining activities on the water resources are mainly manifested in two aspects: First mining activities caused pollution of surface water resources. The performance for the mine sewage emissions, and industrial waste is polluting surface water resources. Especially large mine such is the most serious. Second the mining activities in the deep are impact of underground water. For the performance of deep drainage caused deep underground water pollution, and deep drainage has also caused by the decline of groundwater table, affect the normal circulation of groundwater environment. Third, Because mining dug destroyed mountain, destruction of vegetation, the soil fertility decrease, affect the growth of plants, animal survival environment changes, Mine pressure occupied land, industrial water pollution, industrial noise environmental impact, such as the biological abundance decreased, serious may lead to reduction of species diversity.[4-6]

Mining land accounted for the proportion of forest is as shown in Fig. 1 .

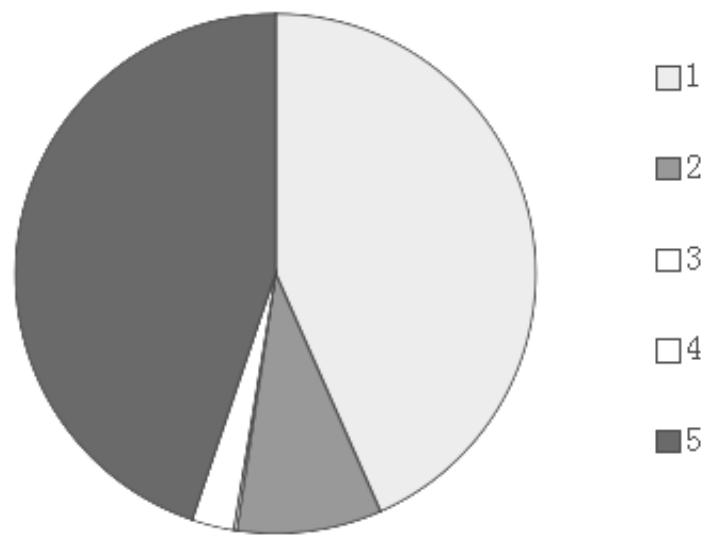

Figure 1. The proportion of forest land occupancy statistics

1-The road project, 2-Water resources protection project,

3-Forest protection project, t4-Coastal wetlands protection project,

5-Land use for mining project

\section{B. Engineering construction project causes}

In the revitalization of northeast old industrial base in economic construction, Dandong New Area Planning High-speed Rail, expressway, construction of water conservancy projects and new urban planning needs a lot of land, But the country does not allow occupation of cultivated land, In the state of arable land under high pressure, The project only occupy a lot of forest land and barren mountain. So some castle destroyed. Especially in some places, random digging soil, the quarry, the destruction of the mountain can be seen everywhere. Such as high speed on both sides of the mountain High-speed Rail, near the city of destruction is very serious. [7 8]

\section{City industrial waste and garbage causes}

It is the National Health City, treatment of industrial waste and waste also has strict provisions, city garbage is classification in Dandong. But because of the cost and personal interests, there are still individual plant, especially private enterprises will steal row abuse the untreated industrial waste and building waste disposal of abandoned, and cause the forest damage suburban mountainous part, this part is mainly concentrated in the suburbs of mountain area[9-10].

\section{Peasants open up wasteland deforestation causes}

Chinese is a traditional agricultural economic powers, farmers rely on farming for a living, so that ruined mountain deforestation, cattle and sheep raising scattered woodland, grazing and other issues still exist. Land reclamation and overgrazing not only directly destroyed afforestation achievement, destroyed the ecological vegetation, encroach on the forest resources, but also caused soil erosion, soil desertification, bare rock, caused serious damage to the ecological environment. Especially in the more than 25 degrees of open up wasteland farming of Castle Peak damage is very serious, it reached 3 million acres in Dandong. 


\section{E. Random interment, chaos to build the cemetery causes}

It has always been a burial customs, due to the improvement of people's living conditions, and appeared the funeral of the bad customs in recent years in China, as the large-scale construction of graves cemetery. It occupies a large number of rural collective forest, including part of scenic area protection area, on both sides of river and urban villages, etc. The reform of funeral and interment should be strengthened, the construction of cemeteries of Green environmental protection imminent should be to strengthened. [10]

\section{COUNTERMEASURES TO PREVENT THE DESTRUCTION OF THE CASTLE PEAK}

Through investigation and research, combined with the work of the Castle Peak protection in Dandong and the actual, the restoration and rehabilitation of the Castle Peak damage should be carried out in the following aspects.

\section{A. The Work and responsibilities of Government decision-making level (should be done)}

1) The government should change ideas, not onesided pursuit of high speed growth of GDP, while ignoring the protection of the ecological environment, but should adhere to the concept of sustainable development, establish a national green ecological awareness, and give priority to the development of green ecological industry.

2) Governments should be the development of green ecological industry as a basic national policy, and make the Development of long-term ecological civilization construction and development planning.

3) The government should set up a full time professional Castle protection functions, coordination of environmental protection, forestry, land and other functions related to the protection of Castle Peak, improve the ecological and environmental monitoring mechanism, clear responsibilities, strengthen the supervision and management of environmental ecological construction.

4) The government should formulate preferential policies, and increase scientific research investment in order to encourage and guide the healthy development of related industries and scientific research.

\section{B. Work of relevant functional departments}

Relevant functional departments should establish a system to strengthen supervision, prevent the generation of new environmental pollution and the destruction of Castle Peak, To carry out scientific guidance for land reclamation and restoration work, at the same time, has been produced by the pollution and Castle Peak damage to targeted governance.

\section{1) Working direction}

a)To strengthen the supervision of mineral development Shut down polluting, serious damage and impact on the ecological environment of small mines; to curb illegal mining and quarrying; remediation shut down mines and tailings; Standardize the approval and construction process of mining development, the formation of environmental priority principle of environmental protection in the construction plan.

b) According to the strict management of the city (town) and key areas of the surrounding mountains; a comprehensive clean-up remediation small reclamation behavior.

c) To strengthen the implementation of the project closing; grazing, scientific guidance, management and improving function of the original ecological restoration of damaged land, optimize the structure of forest economic guidance.

d)Increase the intensity of the ecological restoration efforts on highways, railways and water conservancy projects.

e) To strengthen the supervision and management of forest land, and severely punish the behavior of indiscriminate burial.

\section{2) Concrete work}

First, the wasteland still forest project. Corrected stop engaged in land reclamation and other farming activities in the forest land in accordance with the law, the purpose is to ensure that the forest land ownership, soil and water conservation, water conservation. The project is legally compulsory.

Second, project of Super sloping land restoration to forestry land. Within the area of more than 25 degrees slope in slope land, take the law of returning farmland to forest management at the same time, but also to give economic compensation. On the basis of "The forest law""The water and soil conservation law".

Third, Grazing prohibition Engineering. The required funds from the investment to benefit the main self financing, appropriate government subsidies, the central forestry basic construction projects in accordance with the relevant requirements of the technical regulations and other related requirements, such as appropriate arrangements.

Fourth, closed pit mining ecological restoration project. Closed mine is already stopped mining, according to land department issued the mining license and the prospecting permit is expired to determine, No major closed pit mines is the history of the left over.

Fifth, the production of ecological restoration on mining projects. Is the main part of the land remediation for closed pit larger ore production, generally every 5 years and land departments must organize the preparation of mining enterprises "mine geological environmental protection and control plan" and "mine land reclamation plan", governance responsibilities and expenses borne by the mining enterprises.

Sixth, the ecological restoration and management of highway construction. Highway construction and destruction of the mountain is carried by the transport sector as well as the construction of the owners. The Provincial Department of transportation is charged with Funds required for the management of highway.

Seventh, the ecological restoration and management of the railway construction and destruction. The main responsibility of the construction is the railway owners units; Funds of the construction of railway and the destruction of the ecological management of the mountain is bear by the railway sector units self financing. 
Eighth, The cemetery clean-up remediation. The main body of governance and regulatory responsibility unit is the civil affairs departments at all levels, involving two aspects, first is to strengthen the supervision and management of all kinds of cemetery. second is the supervision and management of the rural areas. third is the cemetery of green cover. Fourth is the implementation of effective customs of funeral reform, reduce the white pollution.

The Work and responsibilities of Enterprise and production unit

Construction units and mining enterprises, according to the regulations and requirements of the government and related departments, establish a green sustainable development concept, mainly to do:

3) Actively cooperate with the relevant functional departments of the relevant requirements of the ecological environment protection, and actively fulfill the obligations of Castle Peak protection and land reclamation.

4) Comply with the construction project design and construction specification procedures, scientific design, scientific management, scientific construction, to ensure that the project to minimize the damage to the ecological environment. Strengthen the protection of ecological environment and the protection of green hills and land reclamation work..

\section{The workand duties of citizen}

On the level of citizens, it is mainly to strengthen the publicity of environmental protection, strengthen the awareness of the construction of ecological civilization, promote and encourage citizens to exercise the supervision rights and rights conferred by law. Supervision of environmental pollution and the destruction of ecological environment by law.

\section{CONCLUSIONS}

Ecological and environmental protection work and Castle Peak protection project is a systematic and longterm work. As the main responsibility, the government should fulfill its responsibilities, scientific planning, scientific regulation and perfect scientific and reasonable supervision mechanism, and promote scientific and reasonable green development concept. As the main responsibility, enterprises should actively carry out environmental protection obligations, establish sustainable development, scientific design, scientific construction, reduce or eliminate the damage and influence caused by production and life. In short, whether it is the government, enterprises and citizens should take positive action to build a high level of ecological civilization, and to do a good job of Castle Peak project, to build a solid foundation for the construction of the new atmosphere in Dandong. Promote economic and social sustainable development.

\section{ACKNOWLEDGMENT}

The article is one of research results of the general project belong to the Education Department of Liaoning province, is get science technology research funds supporting in 2014, Moderator: Bao Yuxue. Item NO.L2014580. It is the research of Liaoning Geology Engineering Vocational College and Dandong Qingshan Bureau cooperation projects. Thanks Shen Fujun, Ji Changlong and Teng Yunlong (Dandong Qingshan Bureau ).

\section{REFERENCES}

[1] YuXue Bao. Analysis on the influence of mining development on the ecological environment in Dandong area. Advanced Materials Research Vol. 707(2015),p243-246,Chemistry and Informatization IV. November-2014

[2] Dandong mineral exploration and Design Co. Ltd. The land reclamation plan report of Limestone mine in the Er Dao Fang village Tong Yuan Pu Town [R]. January -2011

[3] Dandong mineral exploration and Design Co. Ltd. The land reclamation plan report of FuGui Limestone mine in FengCheng [R]. November -2013

[4] ZhongYan Tang .Research of Dandong ecological economic construction.Journal of Shenyang Agricultural University. [J]. January -2009

[5] Bao YuXue. Exploring of land reclamation direction in Open-pit mining of limestone mining area.Mining Engineering $[\mathrm{J}]$, China. March-2014

[6] Wang ShiHe. highway lead content in soil testing and environmental assessment in Dandong area.Technology Innovation Herald. [J]. March-2010.

[7] Bao YuXue, Wang MeiYing, Xiong XiaoYun. Geology of mine [M]. Beijing, Geological Publishing House.July-2009

[8] YuXue Bao. Study on mine materials with exploring for future development direction of resources crisis on mines. Advanced Materials Research Vol. 743 (2013),p257-260,Building Materials and Structural Engineering II . May-2013

[9] Bao YuXue. Geology of mine [M]. Zhengzhou, The Yellow River Water Conservancy Press. August-2015.

[10] YuXue Bao. Research on Ecvironment with Analysis of the Damage Cause for Castle Peak in Dandong. Advances in Materials Environment and Applied TechnogiesIII, P244-251, WIT PRSS,(ESME2015)March-2015. 